\title{
Energy Budget on Various Land Use Areas Using Reanalysis Data in Florida
}

\author{
Chi-Han Cheng, ${ }^{1}$ Fidelia Nnadi, ${ }^{2}$ and Yuei-An Liou ${ }^{3}$ \\ ${ }^{1}$ Applied Hydrometeorological Research Institute, Nanjing University of Information Science \& Technology, \\ No. 219 Ningliu Road, Nanjing, Jiangsu 210044, China \\ ${ }^{2}$ Department of Civil, Environmental and Construction Engineering, University of Central Florida, Orlando, FL 32816, USA \\ ${ }^{3}$ Center for Space and Remote Sensing Research, National Central University, Chung-Li 32001, Taiwan
}

Correspondence should be addressed to Yuei-An Liou; yueian@csrsr.ncu.edu.tw

Received 10 December 2013; Revised 24 March 2014; Accepted 24 March 2014; Published 29 April 2014

Academic Editor: Eugene Rozanov

Copyright (C) 2014 Chi-Han Cheng et al. This is an open access article distributed under the Creative Commons Attribution License, which permits unrestricted use, distribution, and reproduction in any medium, provided the original work is properly cited.

\begin{abstract}
Energy budget is closely related to the hydrological cycle through evapotranspiration (ET) or latent heat. Hence, quantifying the energy budget on different land uses is critical for understanding the water budget and providing useful land use information for decision makers. However, traditional methods, including in situ measurements and model-only approaches, have deficiencies in data availability, and we have still not yet fully realized how well the energy budgets presented in reanalysis data sets. Therefore, in this study, North American regional reanalysis (NARR) data set from 1992 to 2002 were employed to investigate the energy budget on various land uses (lake, wetland, agriculture, forest, and urban) at a regional scale in Florida. The results showed that the lake and urban areas had high values of energy budget, evaporation, and low Bowen ratio, while the wetland areas have the opposite treads because of the lowest evaporation rate. During drought periods, Bowen ratio, surface temperature, and sensible heat were becoming higher than those of normal years conditions. Finally, by comparing with the observed data, we found NARR had better assimilation of precipitation observations and demonstrated the land use effects from the different coefficient of correlation relationships.
\end{abstract}

\section{Introduction}

The surface energy budget closely relates to the hydrological cycle, since evapotranspiration (ET) or latent heat (LE) is a key relationship between energy and water budgets [1]. The partitioning of net radiation markedly depends on the amount of available water on the surface [2-6]. For example, if the soil moisture drops below a critical limit, the available soil water coupled with available energy limit the evaporation rate and finally reduce rainfall and affect the water budget. Therefore, quantifying energy budget above plant canopies is critical for understanding hydrology cycles and provides insights for improving modeling of future regional and global climate regimes $[7,8]$.

Moreover, at the land-atmosphere boundary layer, landatmospheric interactions govern the energy balance and reflect the natural coupling between boundary conditions and rainfall processes $[9,10]$. These interactions affect the daily temperature range, process in the atmospheric boundary layer, cloud cover, rainfall, differential heating, and atmospheric circulations. Hence, land use changes could have both immediate and long-lasting impacts on hydrological processes, altering balance between rainfall and evapotranspiration and the resultant runoff [11]. In short-term impacts, disruptive land use changes disrupt the hydrological cycle either increasing the water yield or through diminishing or even eliminating the low flow in some circumstances [12-14]. While, in long-term impacts, the reductions in evapotranspiration and water recycling arising from land use changes may initiate a feedback mechanism that results in reduced rainfall [15].

However, a disproportional majority of existing energy and water balance studies have been conducted in grasslands and forests, and only few studies have been assessed other land uses such as lake and wetland [16]. For example, these conventional techniques like eddy covariance (EC) and 
Bowen ratio (BR) have applied to several land uses such as grassland [17-21], forests [22-27], mango orchard [28], garlic [29], grapes [30], pecans [31], citrus [32], peach [33], olives [34], grapes [35], and corn soybean [8]. Besides, these conventional techniques do not provide spatial trends (or distribution) at the regional scale especially in regions with advective climatic conditions. Most of climate data come from the meteorological stations, which are point measurements, and weather stations are scarce in remote areas and not uniformly distributed. Further, characterization of the surface hydrologic cycle requires adequate long-term records of not only precipitation but also runoff and evaporation, but such records are lacking in observational data [1].

The NCEP North American regional reanalysis (NARR), which includes model based four-dimensional data assimilation procedures, is a long-term, consistent, high-resolution climate data set for the North American domain [36]. These data sets may provide great possibility for more accurate evaluation of interactions of the land surface and atmosphere. In previous research, we had studied water budgets on various land use areas by using NARR data set, and the results showed that NARR could provide reasonable hydroclimatic variability (e.g., precipitation recycling) and assess the associated impacts of land use/cover change [6]. Therefore, in this study, we try to (1) investigate energy balance on various land uses (lake, wetland, agriculture, forest, and urban) at regional scale, (2) understand how drought events, seasonal, and interannual variations in climatic variables affect the energy and water exchange between atmosphere and land use, and (3) determine how well the energy and water cycles are presented in NARR data sets.

\section{Data Set}

The NARR data, the NCEP regional eta model and its data assimilation system, and a version of the "Noah" land surface mode are the long-term, dynamically consistent, high resolution, high frequency meteorology and hydrology data set for the North American domain [36]. In addition, it adopts many observed quantities in its data assimilation scheme, including gridded analyses of rain gauges precipitation over the continental United States (CONUS), Mexico, and Canada [37]. The data sets and observed variables used in North American regional reanalysis included rawinsondes (temperature, wind, and moisture), dropsondes (temperature, wind, and moisture), pibals (wind), aircrafts (temperature and wind), surface (pressure), and geostationary satellites (cloud drift wind) [36]. Hence, this regional reanalysis is produced at high spatial and temporal resolutions (32 km, 45-layer, 3-hour) and spans a period of 25 years from October 1978 to December 2003. Full details on the NARR products can be found online at http://www.emc.ncep.noaa.gov/mmb/rreanl/.

The strengths of NARR include its assimilation of precipitation observations and its high spatial-temporal resolution. Precipitation assimilation constrains the diurnal cycle of precipitation, which is poorly captured by current convection schemes. Moreover, assimilation of near-surface humidity constrains latent and sensible heat flux partitioning, which is often poorly captured by land surface models $[3,4,6]$. Therefore, it is expected that this dataset will be useful not only for energy and water budget studies but also for analysis of atmosphere land relationships. However, we still need to verify how well the energy budgets are presented in NARR data set in this study. NARR variables in this study are basically a function of the model parameterizations, including latent heat, sensible heat, and surface temperature. The study here applies the 11-year period of NARR analyses from 1992 through 2002, utilizing monthly averages of the data.

\section{Study Area}

The climate in Florida is subtropical, humid with a rainy, wet season extending from May through October. Most areas in Florida receive at least 1270 millimeters of rain annually. The long-term annual mean temperature is 22.4 $( \pm 0.6)^{\circ} \mathrm{C}$ based on historical records of a weather station located in Kissimmee, Florida (Southeast Regional Climate Center, http://www.sercc.com/). This state, however, has large variations in total annual precipitation. Floods that occur one year may be followed by drought the next year [38].

3.1. ENSO in Florida. In Florida, EI Niño-Southern Oscillation (ENSO) often influences temperature, precipitation, and upper-level wind, which in turn results in flood, drought, and wildfires [39]. These impacts are stronger during winter and spring months than the summer months. A strong EI Niño phenomenon occurred in fall and winter of 19971998 when rainfall was above normal for most of the state and temperature was cooler. Nevertheless, by late 1998, a strong La Niña event was in effect, which continued through 2001 [40]. The La Niña brings higher temperature and dry weather in Florida. Lower than normal precipitation caused a severe statewide drought in Florida during period of time. According to Wildfire statistics, it showed 25,137 fires burned 1.5 million acres between 1998 and 2002 [41]. Finally, rainfall that occurred in late 2002, in 2003, and from a tropical storm and four hurricanes in 2004 ended this drought.

3.2. The Selected Areas. In this study, data from 1992 national land cover dataset on five different land uses in six $32 \times 32 \mathrm{~km}$ regional study areas were selected as shown in Figure 1. These land uses include urban, forest, and agriculture in Northeast Florida, lake, wetland, and agriculture in South Florida based on Florida's different climatic zones (Figure 2). In the northeast of Florida, the climate is somewhat cooler and receives abundant precipitation between 1000 and $1500 \mathrm{~mm}$ annually, thus enabling the production of specialized crops. Therefore, a regional agriculture land use, located in west Alachua and devoted to forage, hay production and silage corn, was selected for studying the energy budget. Moreover, the Ocala National Forest area was selected as a regional forest land use area because extensive pine plantations are relatively common in North Florida [42]. Finally, we chose the urban area, Jacksonville, for the study area because substantial population growth has occurred, causing an expansion of 


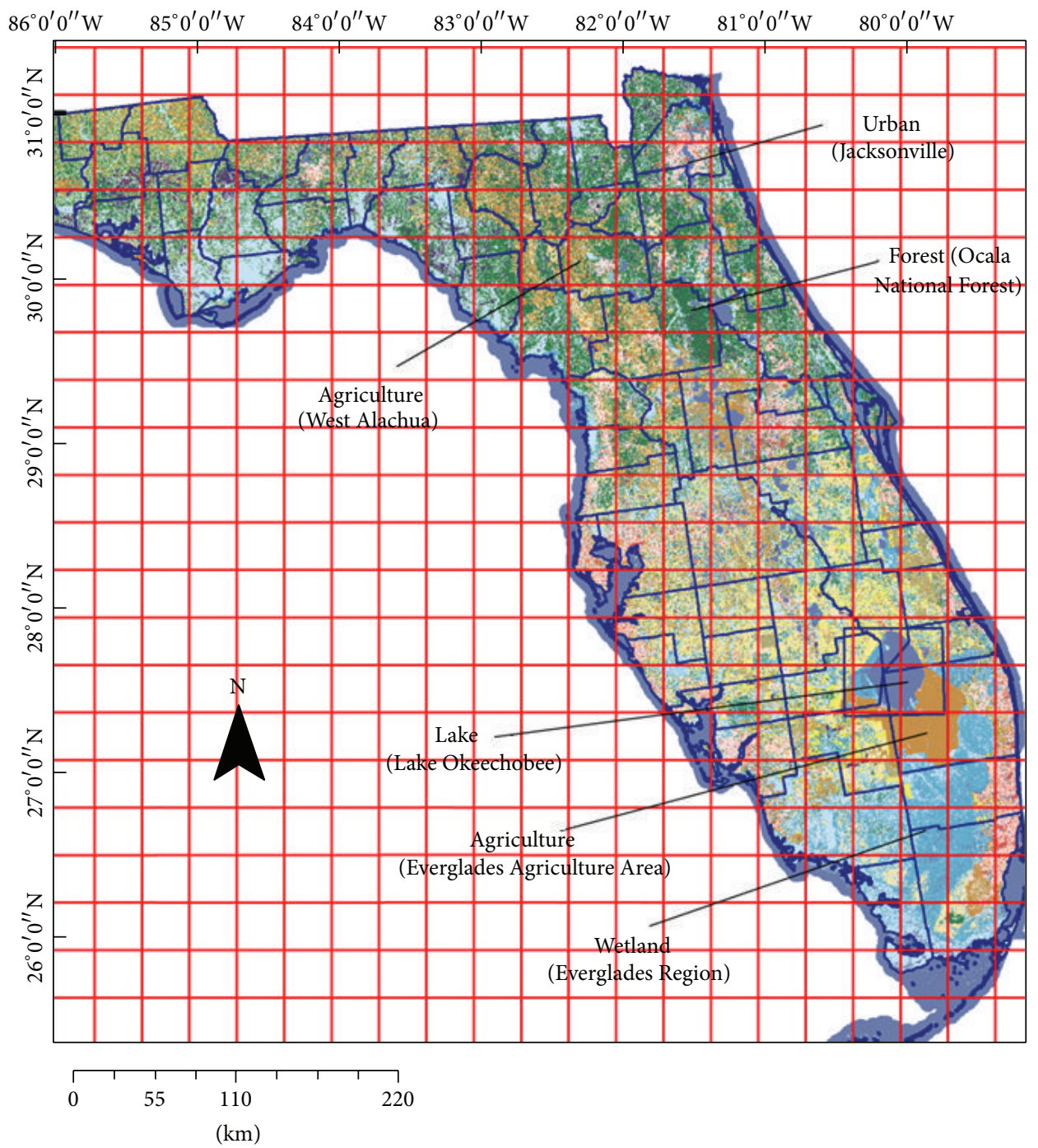

NLCD 1992 land cover classification legend

11 open water
12 perennial ice/snow
21 low intensity residential
22 high intensity residential
23 commercial/industrial/transportation
31 bare rock/sand/clay
32 quarries/strip mines/gravel pits
33 transitional barren
41 deciduous forest
42 evergreen forest
43 mixed forest

51 shrubland
61 orchards/vineyards/other
71 grassland/herbaceous
81 pasture/hay
82 row crops
83 small grains
84 fallow
85 urban/recreational grasses
$\square 1$ woody wetlands
92 emergent herbaceous wetlands

Figure 1: Six selected $32 \times 32 \mathrm{~km}^{2}$ regional study areas along with land use/land cover from the 1992 national land cover dataset. The red gridline is a $32 \times 32 \mathrm{~km}^{2}$ resolution grid from North American regional reanalysis dataset (revised from [6]).

urban and developed land. Within 30 years, the population is increased by more than 140 percent, suggesting larger urban areas as in Orlando, St. Petersburg, Tampa, and Jacksonville.

While, in the South Florida, the climate is generally frostfree and subtropical and annual rainfall is about $1400 \mathrm{~mm}$. The main regional characteristics are wetland, lake, agriculture, and urban areas (Figure 1). The Everglades region is a subtropical wetland that covered much of South Florida and comprises over 4000 square miles stretching from Lake Okeechobee in the north to the Florida Bay at the southern end of the peninsula. Hence, it was selected to represent the regional $32 \times 32 \mathrm{~km}$ grid of wetlands in South Florida. Lake Okeechobee (Figure 1), the second largest freshwater lake in the U.S covering a surface area of 1800 square $\mathrm{km}$, 


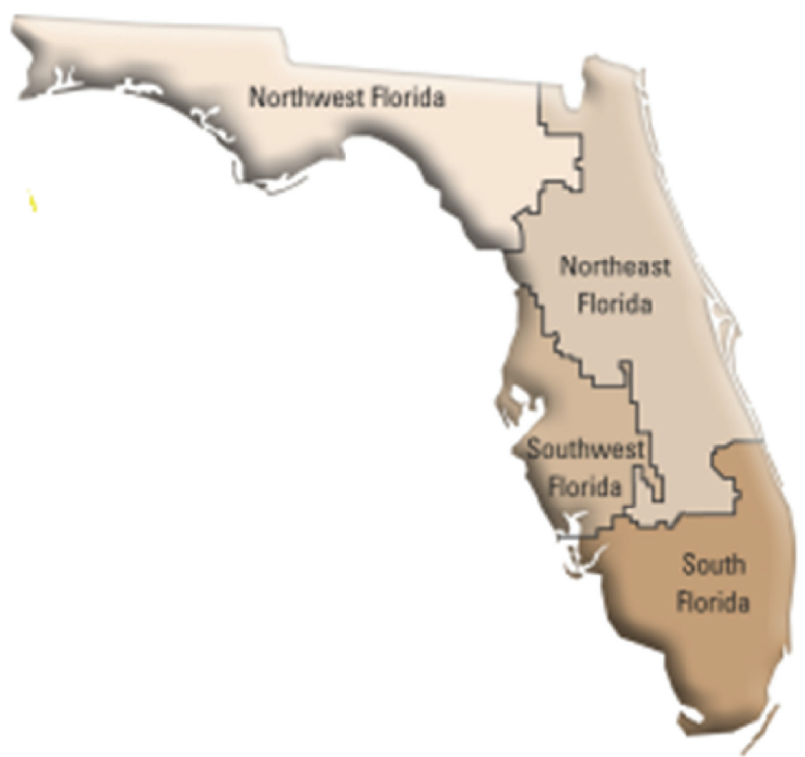

Figure 2: Map of Florida depicting the four regions of the state [40].

with an average depth of $2.7 \mathrm{~m}$, is a large, shallow, eutrophic lake located in South Central Florida and is frequently hit by hurricanes. As the central part of a larger interconnected aquatic ecosystem and as the major surface water body, Lake Okeechobee provides a number of societal and environmental service functions including water supply for agriculture and urban areas [43]. Therefore, investigating impacts of drought events on the lake is very critical and necessary. Finally, the Everglades Agriculture Area (EAA), a small portion of the Everglades Region consisting of artificially rich organic soil supporting a thriving agriculture industry with annual benefits around $\$ 500$ million, was also considered for the study [44]. Comparing national land cover dataset of two different periods of 10 years interval, Figures 1 and 3 , the land use changes could be monitored and detected. The regional agriculture land use, which is located in West Alachua, changed the land use from row crop in 1992 to pasture hay in 2001, but other land use areas did not change appreciably within the 10 -year period. Hence, in this study, we assumed land use types of the selected areas did not have huge differences from 1992 to 2002 (Figures 1 and 3).

\section{Methodology}

4.1. Energy Budget. Monthly data from 1992 through 2002 NARR data set that includes latent heat, sensible heat, and surface temperature were utilized to evaluate energy budgets on various land uses using the energy balance equation expressed as

$$
R_{n}=H+L E+G,
$$

where $R_{n}$ is net radiation flux at interface between land cover and atmosphere; $G$ is conductive soil heat flux; $H$ represents sensible heat (heat exchange by convection); and $L E$ is latent heat (water vapor condensation or water evaporation from surfaces and plant transpiration). The conductive soil heat flux would be neglected in this equation because it is relatively small [45]. The ratio of $H$ and $L E$ is used to calculate the Bowen ratio, $B$.

4.2. Monthly Anomaly Pattern. To determine anomaly trends during the study period, the monthly averages of the climatology parameters, which include actual evaporation, latent heat, sensible heat, and surface temperature, were calculated. Individual monthly anomaly was then calculated as percent departure from the 11 years average of monthly averages using

$$
P_{a}=\left(\frac{\left(P_{o}-P_{m}\right)}{P_{m}}\right) \times 100,
$$

where $P_{a}$ is the respective monthly percent anomalies, $P_{o}$ is monthly climatology parameters, and $P_{m}$ is the long-term average of climatology parameters.

\section{Results and Discussions}

In this study, seasonal, interannual variations and land use effects would be considered in analyzing the 11-year NARR data set. Figure 4 showed the average latent heat in Northeast Florida. In Northeast Florida, for the different land use types, the trade of average latent heat is decreased from 1992 to 2002. The highest annual latent heat was on the agriculture area in 1996 of $96.33 \mathrm{~W} / \mathrm{m}^{2}$, while the lowest value was in 2000 of $73.67 \mathrm{~W} / \mathrm{m}^{2}$ on the agriculture area.

Figure 5 presented the average annual latent heat in South Florida. The average annual latent fluctuated from 1992 to 1999 and reached the highest values in 1998 on the agriculture, wetland areas and in 1999 on the lake area. Next, the values are declined and reached the lowest values in 2001 on the three study areas. Finally, the tread went up in 2003. In Table 1, the maximum and minimum values of latent heat on the selected land use areas in both regions are presented with the years of occurrence. From Table 1, we find that the selected areas had the lowest latent heat during the drought years.

The seasonal variations of the average monthly latent heat in Northeast Florida were shown in Figure 6, while those of South Florida were presented in Figure 7. In Northeast Florida, higher average values of monthly latent heat were observed between April and September, on the urban and forest areas, while on the agriculture area, the higher values occur in July and lower values were observed in December and January. These variations were listed in Table 2 for the selected land use areas. In South Florida, the wetland area, located in the Everglades, had the highest values of average monthly actual evaporation and latent heat in June, with values of $3.43 \mathrm{~mm} /$ day and $99.09 \mathrm{~W} / \mathrm{m}^{2}$, respectively. It has been suggested that much of the rainfall in South Florida is based on the evaporation in the Everglades [46]. The authors also suggested that the effect of water vapor movement from the ocean to the north due to wind action induces evaporation on the Lake Okeechobee area and the surrounding agriculture area (Figures 1 and 3), leading to higher values of actual evaporation in July and August. Lower values were observed in winter (see Table 2). 

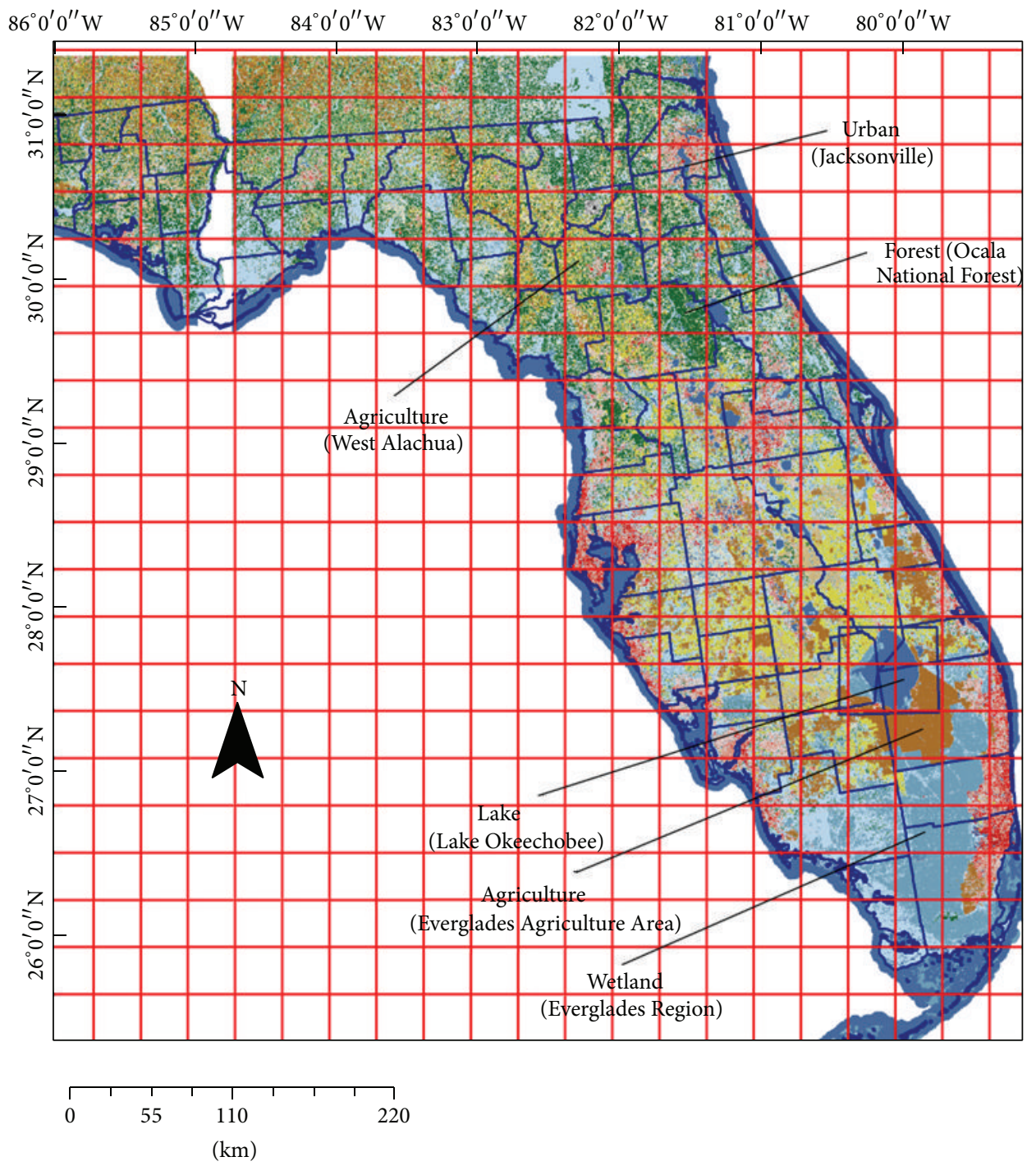

NLCD 2001 land cover classification legend
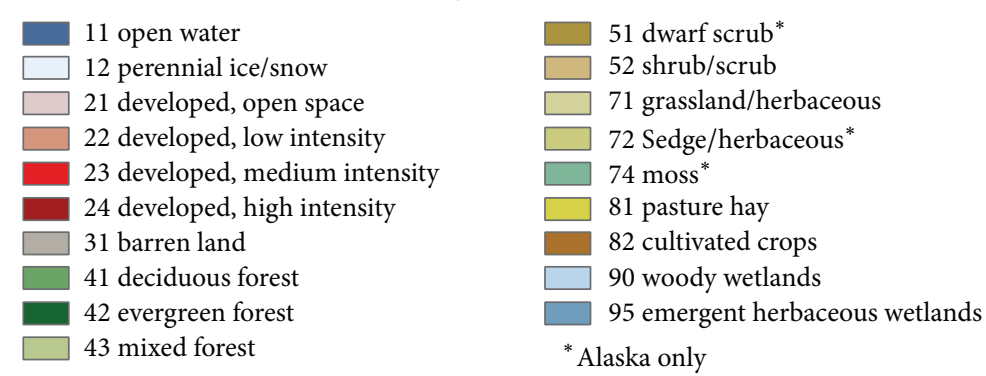

Figure 3: Six selected $32 \times 32 \mathrm{~km}^{2}$ regional study areas along with land use/land cover from the 2001 national land cover dataset. The red gridline is a $32 \times 32 \mathrm{~km}^{2}$ resolution grid from North American regional reanalysis dataset (revised from [6]).

5.1. Monthly Actual Evaporation and Latent Heat Anomaly. Figure 8 showed the time series of monthly latent heat anomaly trends for the Northeast Florida. These anomalies were positive from March to September on the three land uses, with the values between $0.84 \%$ and $50.09 \%$. However, during the drought years, March 2000 through 2001, these anomalies dropped to negative values in all study areas as shown in Figure 8.

Figure 9 suggest that the positive anomalies in the latent heat values range from $0.79 \%$ to $47.23 \%$ for March and October. However, in May, the lake area had negative values in latent heat, and negative values were also observed during 
TABLE 1: Annual variation of actual evaporation and latent heat flux in the selected land use areas.

\begin{tabular}{|c|c|c|c|c|c|c|}
\hline \multirow{2}{*}{ Land use } & \multicolumn{2}{|c|}{ Actual evaporation $(\mathrm{mm} / \mathrm{d})$} & \multicolumn{2}{|c|}{ Latent heat flux $\left(\mathrm{W} / \mathrm{m}^{2}\right)$} & \multicolumn{2}{|c|}{ Year reported } \\
\hline & Maximum & Minimum & Maximum & Minimum & Maximum & Minimum \\
\hline \multicolumn{7}{|c|}{ Northeast Florida Region } \\
\hline Urban & 3.20 & 2.88 & 96.27 & 83.17 & 1992 & 2001 \\
\hline Forest & 3.11 & 2.66 & 90.00 & 77.00 & 1995 & 2000 \\
\hline Agriculture & 3.23 & 2,54 & 93.33 & 73.67 & 1995 & 2000 \\
\hline \multicolumn{7}{|c|}{ South Florida Region } \\
\hline Lake & 3.53 & 3.08 & 102.42 & 89.08 & 1999 & 2001 \\
\hline Wetland & 2.69 & 2.33 & 77.50 & 67.58 & 1993 & 2001 \\
\hline Agriculture & 3.34 & 2.48 & 96.75 & 72.25 & 1995 & 2001 \\
\hline
\end{tabular}

TABLE 2: Seasonal variation of monthly actual evaporation and latent heat flux in the selected land use areas.

\begin{tabular}{|c|c|c|c|c|c|c|}
\hline \multirow{2}{*}{ Land use } & \multicolumn{2}{|c|}{ Actual evaporation $(\mathrm{mm} / \mathrm{d})$} & \multicolumn{2}{|c|}{ Latent heat flux $\left(\mathrm{W} / \mathrm{m}^{2}\right)$} & \multicolumn{2}{|c|}{ Months reported } \\
\hline & Max & Min & Max & Min & Max & Min \\
\hline \multicolumn{7}{|c|}{ Northeast Florida Region } \\
\hline Urban & 3.93 & 1.90 & 113.63 & 55.72 & July & January \\
\hline Forest & 4.00 & 1.52 & 115.36 & 43.72 & July & December \\
\hline Agriculture & 4.35 & 1.49 & 126.00 & 43.18 & July & December \\
\hline \multicolumn{7}{|c|}{ South Florida Region } \\
\hline Lake & 3.83 & 2.93 & 110.90 & 84.72 & August & February \\
\hline Wetland & 3.43 & 1.52 & 99.09 & 44.09 & June & December \\
\hline Agriculture & 4.21 & 1.76 & 110.90 & 50.81 & July & January \\
\hline
\end{tabular}

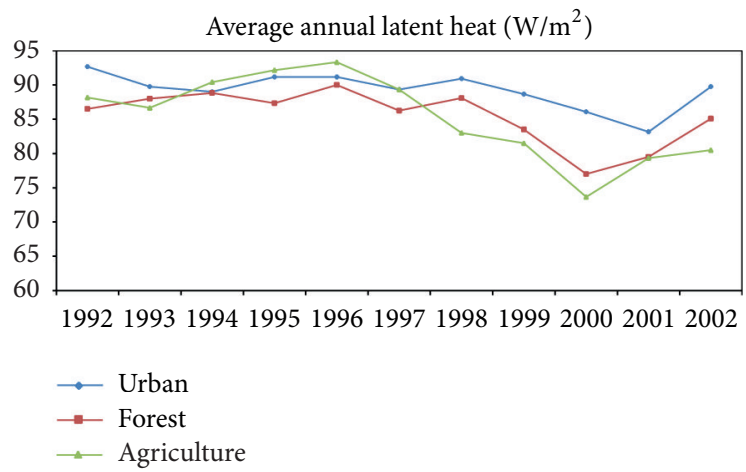

FIgURE 4: Average annual actual latent heat in Northeast Florida.

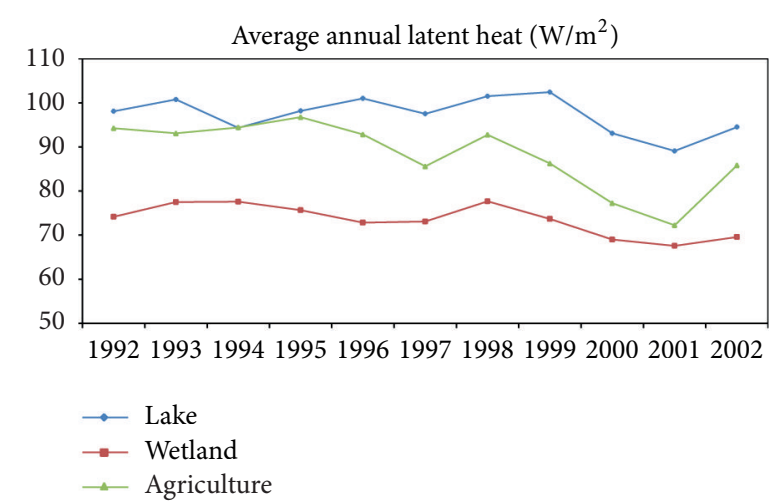

Figure 5: Average annual latent heat in South Florida.

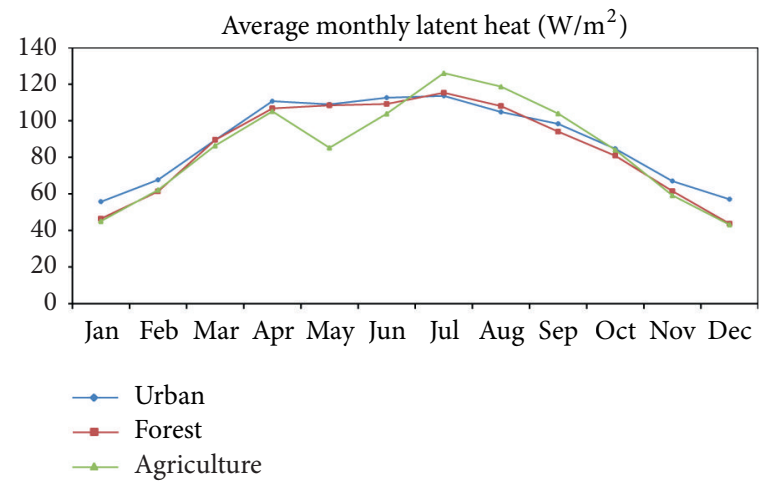

FIGURE 6: Average monthly latent heat in Northeast Florida.

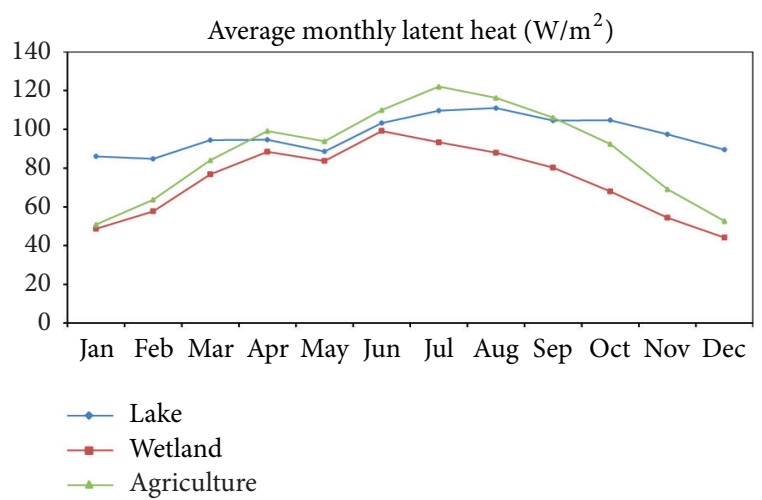

FIGURE 7: Average monthly latent heat in South Florida. 


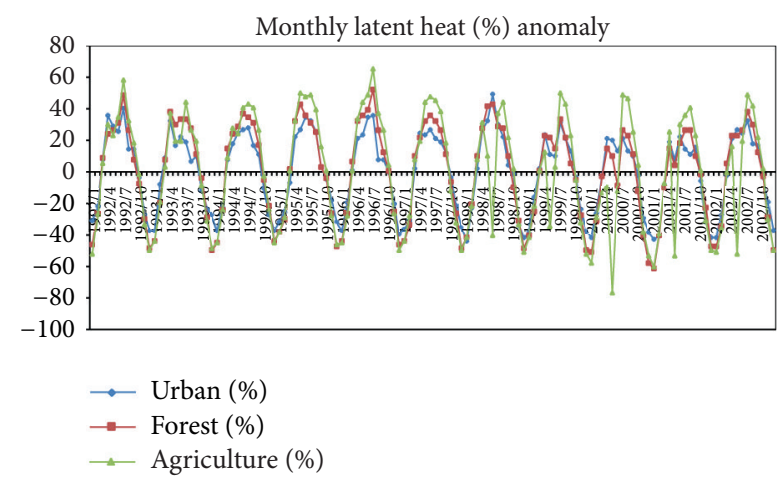

FIGURE 8: Time series monthly latent heat anomaly trends for Northeast Florida.

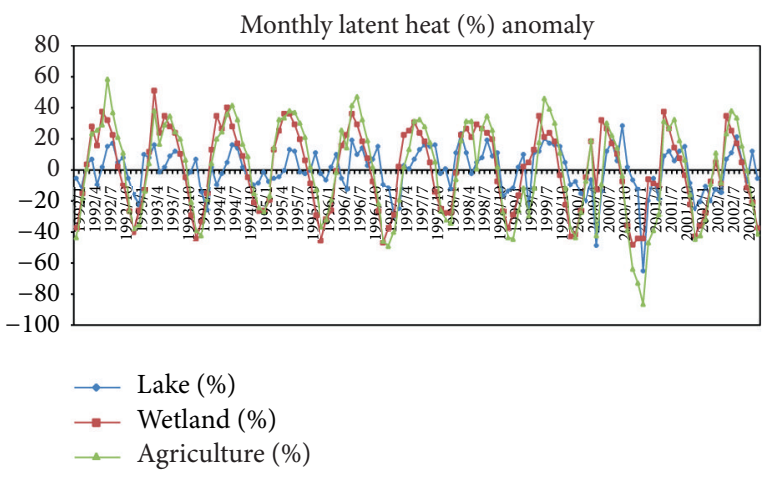

FIgURE 9: Time series monthly latent heat anomaly patterns for South Florida.

the drought years for all research areas, except in April of both drought years for the wetland and agriculture areas.

5.2. Monthly Sensible and Heat Variations. Based on the energy budget (1), the available land surface energy was partitioned into latent heat and sensible heat, and as more energy partitioned into latent heat, less energy converted to sensible heat. Figures 10(a) and 10(b) showed the average annual and monthly sensible heat in Northeast Florida for all land use areas. During drought years, most of land surface energy would be partitioned into sensible heat. Hence higher sensible heat was observed on the urban, forest, and agriculture area with values of $44.08 \mathrm{~W} / \mathrm{m}^{2}, 51.5 \mathrm{~W} / \mathrm{m}^{2}$, and $51.8 \mathrm{~W} / \mathrm{m}^{2}$, respectively. Also, during the summer and fall seasons, most of surface energy would convert to latent heat for evaporation thus resulting in lower values of sensible heat from June to December in Northeast Florida. Hence, on all three land uses, lower average monthly sensible heat values were observed as $23 \mathrm{~W} / \mathrm{m}^{2}$ and $57.63 \mathrm{~W} / \mathrm{m}^{2}$ in summer and fall, respectively, while the higher values were observed in winter and spring, as $25.09 \mathrm{~W} / \mathrm{m}^{2}$ and $84.09 \mathrm{~W} / \mathrm{m}^{2}$, respectively.

In the south, the average annual and monthly values of the sensible heat also varied with land uses as shown in Figures 11(a) and 11(b). These annual values range from $41 \mathrm{~W} / \mathrm{m}^{2}$ in $2000,55.41 \mathrm{~W} / \mathrm{m}^{2}$ in 2000 , and $51.58 \mathrm{~W} / \mathrm{m}^{2}$ in
2001 on the lake, wetland, and agriculture areas, respectively. During summer and fall seasons, when most of the land surface energy converted to latent heat for evaporation, lower sensible heat values were observed on the three land uses, with values between $15.18 \mathrm{~W} / \mathrm{m}^{2}$ and $45.54 \mathrm{~W} / \mathrm{m}^{2}$. The higher values of the average monthly sensible heat were in April on the wetland and agriculture areas, with values of $77 \mathrm{~W} / \mathrm{m}^{2}$ and $67.54 \mathrm{~W} / \mathrm{m}^{2}$, respectively, and in May on the lake, with the values of $44.54 \mathrm{~W} / \mathrm{m}^{2}$.

5.3. Monthly Sensible Latent Heat Anomaly. Interannual variations in monthly sensible heat in Northeast Florida were shown in Figure 12(a). In normal years, monthly sensible heat anomalies were negative from June to January, with values between $-0.71 \%$ and $-54.88 \%$, while the positive values were from February to May, with values between $0.88 \%$ and $58.32 \%$ for all three land use areas. However, during the drought years, the positive sensible heat anomalies were shown in June 1998, from June to August in 1999 and 2000, with values between $0.84 \%$ and $263.57 \%$ on all three land uses. It has been suggested that soil moisture acts as a strong control on the partitioning between sensible heat flux and latent heat flux at the surface (the Bowen ratio) modulating precipitation over a given basin $[47,48]$. Hence, different land use types have different responses to the drought events. For example, the agriculture area, which has sallow roots containing lower soil moistures, had highest sensible heat anomalies in June 1998, May of 1999 through 2002, and April 2000, with values between $183.95 \%$ and $308.68 \%$, while other land use areas such as the urban and forest areas just had higher anomalies during the drought period.

It has also been suggested that surface temperature is a factor in sensible heat variation and transfer. When the surface is warmer than the air above, heat will be transferred upward into the air as positive sensible heat to warm up air temperature. Figure 12(b) presented interannual variations in monthly surface temperatures in Northeast Florida. In normal years, the monthly surface temperature anomalies were negative from November to April, with values between $-0.67 \%$ and $-46.34 \%$, while the positive values were from May to October, with values between $2.84 \%$ and $36.82 \%$. During the drought years, however, higher surface temperatures transferred higher sensible heat, which resulted in a higher surface temperature anomaly in June 1998, with a value of $53.95 \%$, and a higher sensible heat over the agriculture area, with a value of $269.57 \%$.

Figure 13(a) showed the interannual variations in monthly sensible heat in South Florida. In normal years, negative monthly sensible heat anomalies were observed from June to December, with the values between $-2.67 \%$ and $-68.4 \%$, while the positive anomalies were observed from February to May, with values between $0.68 \%$ and $68.52 \%$ on the three land uses. During drought years, the sensible heat anomalies were from February to May, especially on the lake and agriculture areas, with the values between $30.89 \%$ and $188.63 \%$, respectively.

Figure 13(b) presented the interannual variations in monthly surface temperature in South Florida. In normal 


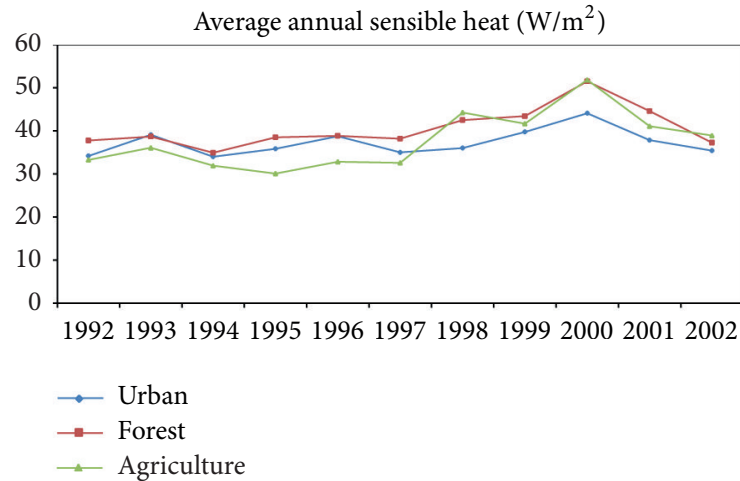

(a)

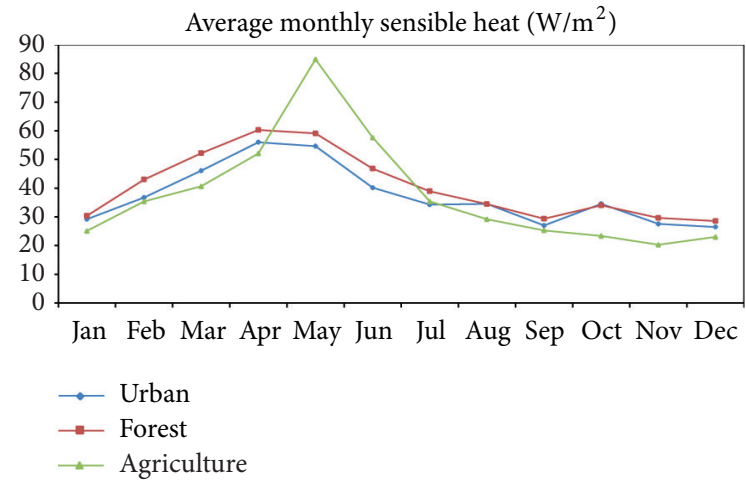

(b)

Figure 10: (a) Average annual sensible heat in Northeast Florida. (b) Average monthly sensible heat in Northeast Florida.

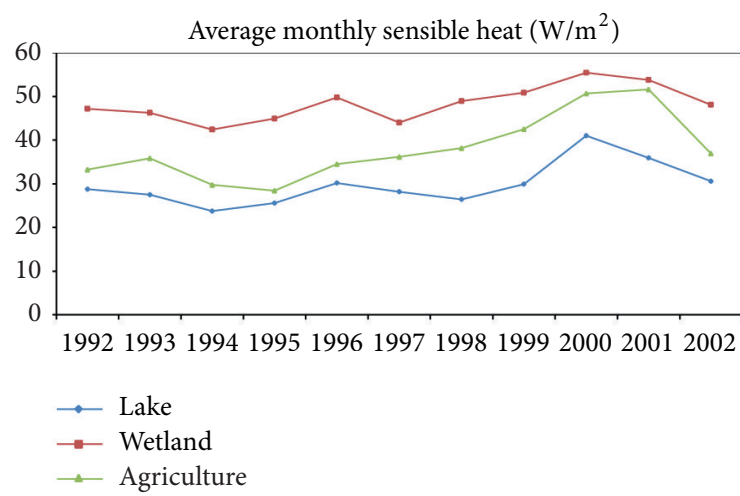

(a)

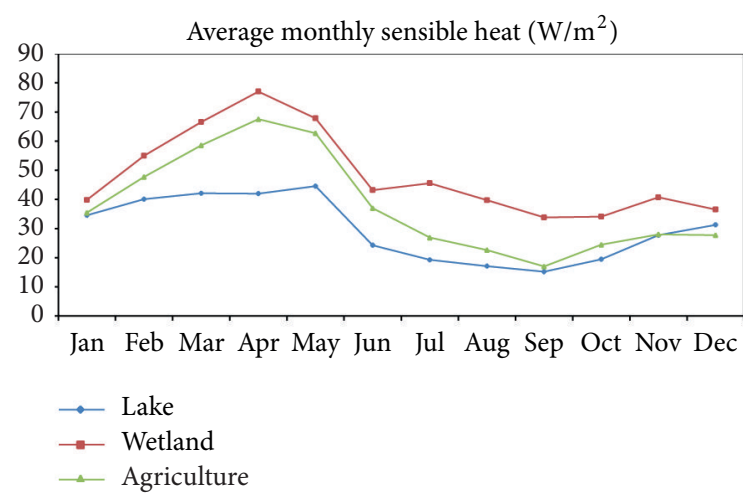

(b)

Figure 11: (a) Average annual sensible heat in South Florida. (b) Average monthly sensible heat in South Florida.

years, high values occurred between April and May with values between $1.05 \%$ and $23.07 \%$. During the drought years, the lake and agriculture areas had higher surface temperature anomalies with higher values in April to May of 1999 through 2002 , with values between $6.54 \%$ and $29.57 \%$.

5.4. Monthly Bowen Ratio. During drought, the Bowen ratio is higher suggesting that partitioning of net radiation is skewed, with more heat going into the sensible heat flux and less into the latent flux. The increased sensible heat flux acts to heat the canopy and boundary layer. Figures 14(a) and 14(b) show the average annual Bowen ratio in Northeast and South Florida, respectively. Hence, during the drought years, higher Bowen ratios were shown on the agriculture areas with values of 1.19 in 2000 in Northeast Florida and 1.5 in 2001 in South Florida. This shift indicates that increased sensible heat was gained compared to latent heat as water flux from the ecosystem abruptly decreased.

Figures 15(a) and 15(b) show the average monthly Bowen ratio in Northeast and South Florida, respectively. The seasonal variation was clearly concave-sharped and the lower values occurred from June to September, with a range of 0.24 and 0.69 in Northeast Florida and 0.14 and 0.48 in South Florida. Higher values were observed in early spring, with values between 0.47 and 1.79 in Northeast Florida and 0.45 and 1.32 in South Florida.

5.5. Monthly Bowen Ratio Anomaly. Figures 16(a) and 16(b) show the interannual variations in monthly Bowen ratio in Northeast and South Florida, respectively. In Northeast Florida, during the drought year, the values of Bowen ratio were high on the three land use areas with the agriculture area as the highest in May. This suggests that a decrease in evapotranspiration through the growing season due to the decrease of soil moisture and maintenance of the energy balance through changes in the sensible heat and latent heat flues. While in South Florida the highest sensible heat flux occurred in February of 2001 when the surface temperature was above normal by $11.96 \%$, hence showing negative anomalies. It was also noted that under drier conditions, the availability of soil moisture becomes the primary source of moisture for ET, which strongly controls Bowen ratio and therefore affects the surface temperature and evaporation rate.

5.6. Energy Budget Balance. Tables 3 and 4 presented the 11year mean energy budget terms for the selected land use areas in Northeast and South Florida, respectively. In this study, 


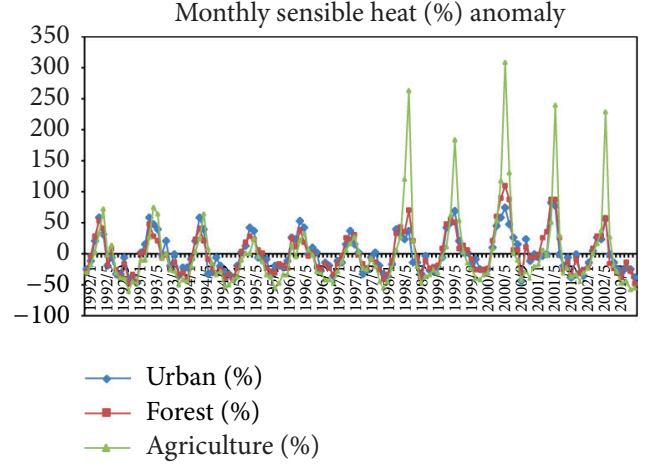

(a)

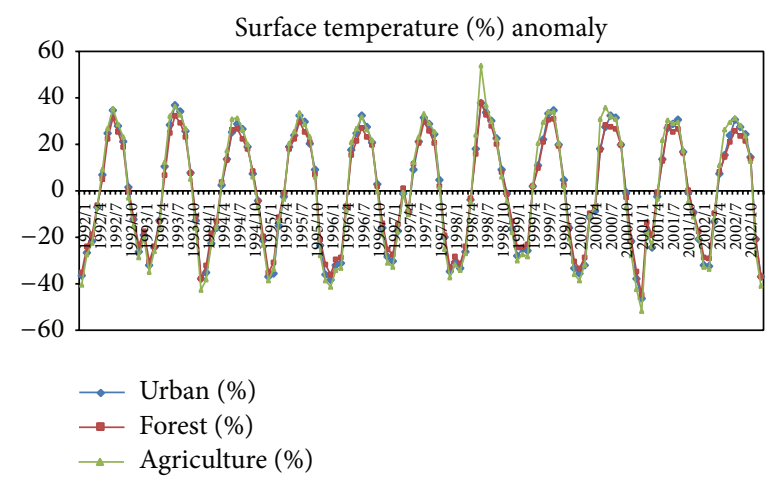

(b)

Figure 12: (a) Time series monthly sensible heat anomaly patterns for Northeast Florida. (b) Time series monthly surface temperature anomaly patterns for Northeast Florida.

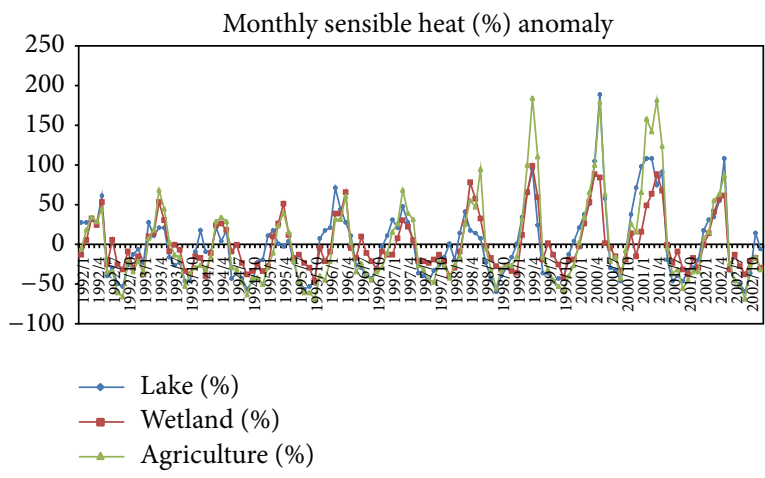

(a)

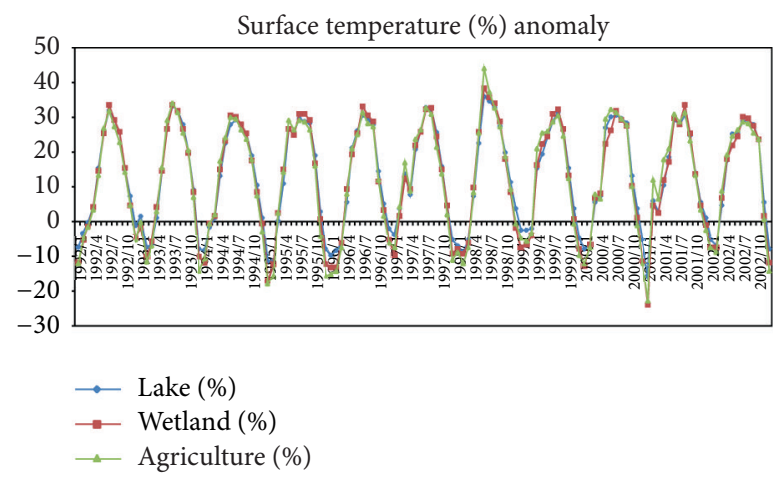

(b)

FIGURE 13: (a) Time series monthly sensible heat anomaly patterns for South Florida. (b) Time series monthly surface temperature anomaly patterns for South Florida.

the total net radiation is defined as the summation of latent and sensible heat, and the evaporation rate is defined as the ratio of latent heat/net radiation. In Northeast Florida, the urban area located at St. Johns River had the highest net radiation, latent heat, evaporation rate, actual evaporation, and lower sensible heat, while the agriculture area had lower net radiation and latent heat. In South Florida, the lake area had the highest net radiation, latent heat, evaporation rate, and lower sensible heat and Bowen ratio. However, because wetlands have hydric soil, which keeps water on the surface, the net radiation, latent heat, evaporation rate, and actual evaporation were lower, while the sensible heat and Bowen ratio were higher. In general, the agriculture area had a similar Bowen ratio, with a value of 0.55 in both study areas. The open area was observed to have the lowest Bowen ratio, and the wetland had the highest. In the report by [49], they provided in situ mean monthly weather parameters data (from 1994 to 2003) from a weather station at a constructed wetland (at Stormwater Treatment Area 1 West), including actual evaporation and rainfall data. Hence, we compared actual evaporation from NARR and in situ data, and results showed that the NARR data set would significantly underestimate evaporation on May while overestimate on the lake area from October to January (see Figure 17(a)). We also calculated coefficient of correlation between the NARR and observations data. The results indicated that the wetland area had the highest coefficient of correlation, 0.92, while the lake area had the lowest one, 0.37. Finally, Figure 17(b) demonstrated that the NARR has good relationships with the observations in mean monthly rainfall data, and the coefficients of correlation were 0.94 on the three study areas. Hence, in conclusion, NARR had better assimilation of precipitation observations and could reflect land use effects that are in the actual evaporation estimation; the wetland areas demonstrated the highest coefficient of correlation with the same land use type observations data.

\section{Summary and Conclusions}

In this study, NARR data set from 1992 to 2002 were employed to investigate the energy budget on various land uses (lake, wetland, agriculture, forest, and urban) at regional scale in Florida. In Northeast Florida, the urban area had higher 


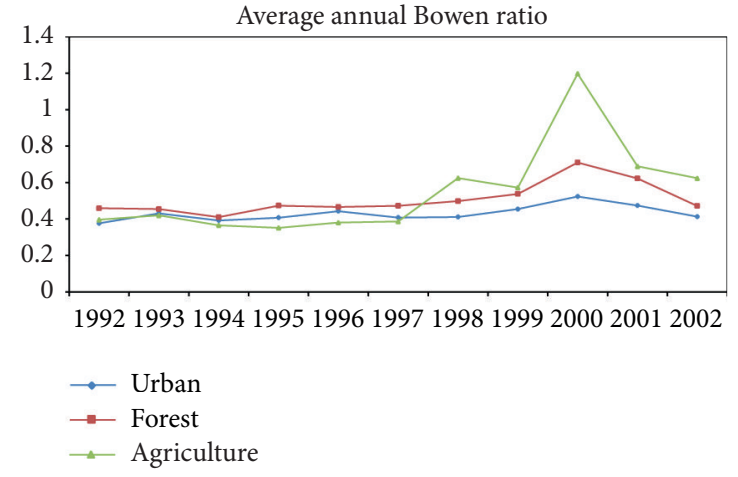

(a)

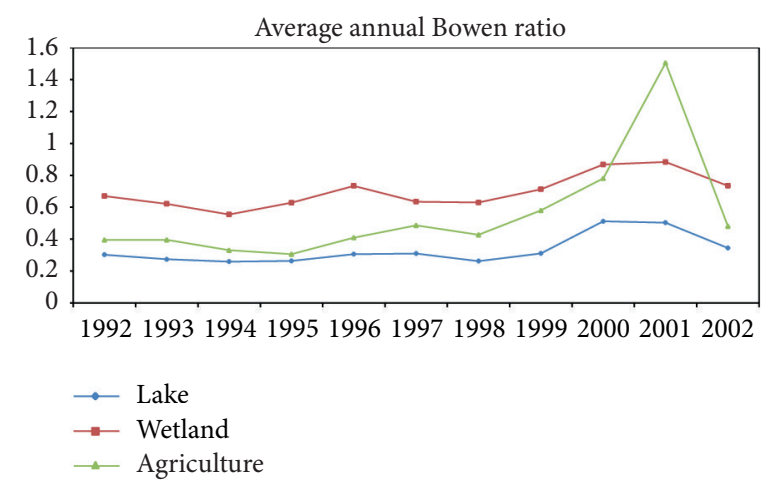

(b)

Figure 14: (a) Average annual Bowen ratio in Northeast Florida. (b) Average annual Bowen ratio in South Florida.

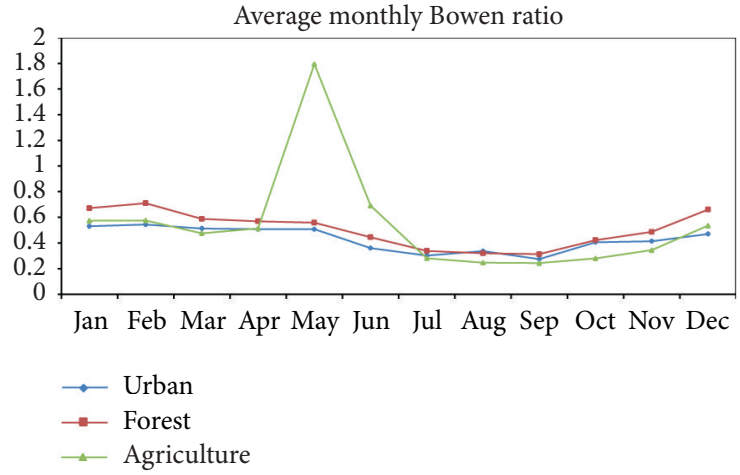

(a)

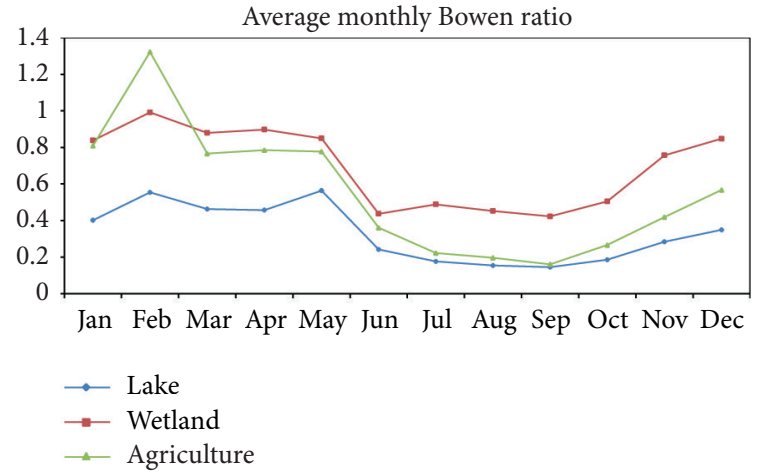

(b)

Figure 15: (a) Average monthly Bowen ratio in Northeast Florida. (b) Average monthly Bowen ratio in South Florida.

TABLE 3: Annual mean (1992-2001) energy budget for various land uses in Northeast Florida.

\begin{tabular}{lccc}
\hline Energy budget & Urban & Forest & Agriculture \\
\hline Net radiation $\left(\mathrm{W} / \mathrm{m}^{2}\right)$ & 126.424 & 126.015 & 122.962 \\
Latent heat $\left(\mathrm{W} / \mathrm{m}^{2}\right)$ & 89.159 & 85.462 & 85.280 \\
Sensible heat $\left(\mathrm{W} / \mathrm{m}^{2}\right)$ & 37.265 & 40.553 & 37.682 \\
Evaporation rate & 0.703 & 0.672 & 0.695 \\
Actual evaporation $(\mathrm{mm} /$ day) & 3.085 & 2.956 & 2.948 \\
Bowen ratio & 0.430 & 0.507 & 0.546 \\
\hline
\end{tabular}

TABle 4: Annual mean (1992-2001) energy budget for various land uses in South Florida.

\begin{tabular}{lccc}
\hline Energy budget & Lake & Wet land & Agriculture \\
\hline Net radiation $\left(\mathrm{W} / \mathrm{m}^{2}\right)$ & 127.11 & 121.80 & 126.27 \\
Latent heat $\left(\mathrm{W} / \mathrm{m}^{2}\right)$ & 97.31 & 73.48 & 88.30 \\
Sensible heat $\left(\mathrm{W} / \mathrm{m}^{2}\right)$ & 29.80 & 48.32 & 37.98 \\
Evaporation rate & 0.77 & 0.60 & 0.70 \\
Actual evaporation $(\mathrm{mm} /$ day) & 3.37 & 2.54 & 3.05 \\
Bowen ratio & 0.33 & 0.70 & 0.55 \\
\hline
\end{tabular}

net radiation, latent heat, evaporation rate, lower sensible heat and Bowen ratio, while the agriculture area had lower net radiation, latent heat, actual evaporation, and higher Bowen ratio. In South Florida, Lake Okeechobee (lake) had higher net radiation, latent heat, evaporation rate, actual evaporation, lower sensible heat, and Bowen ratio, while the wetland area had lower net radiation, latent heat, evaporation rate, higher sensible heat, and Bowen rate because of lower evaporation. From the annual energy budgets, the agriculture in both study areas had similar Bowen ratio therefore suggesting that Bowen ratio may be used for identifying the characteristics of different land uses.

Under wet conditions, ET is principally limited by the atmospheric demand of water vapor, driven by advection and radiation. This suggests why the lake areas have higher actual evaporation, latent heat, evaporation rate, and lower Bowen ratio with higher net radiation. However, during the drought year, most of the surface energy would be partitioned into sensible heat and, hence, lower average annual evaporation and latent heat as shown by various land uses with higher average monthly sensible heat in summer and fall seasons. Moreover, during drier conditions, the availability of soil moisture becomes the primary control of ET, and the differences in plants response to access water often dictated by the rooting depth can result in contrasting evaporative losses across vegetation types [50]. Therefore, in Northeast Florida, negative evaporation and latent heat were observed 


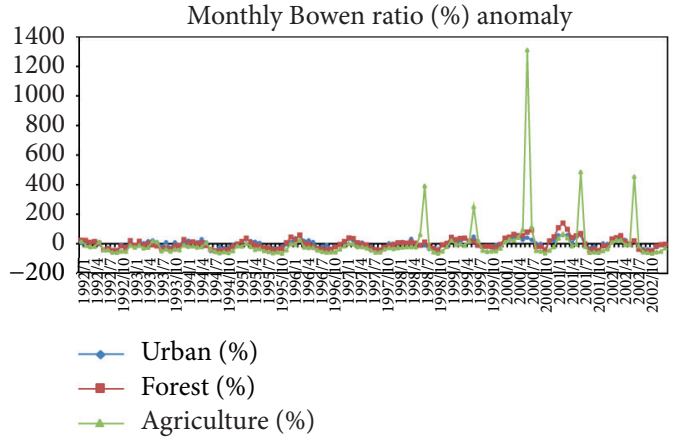

(a)

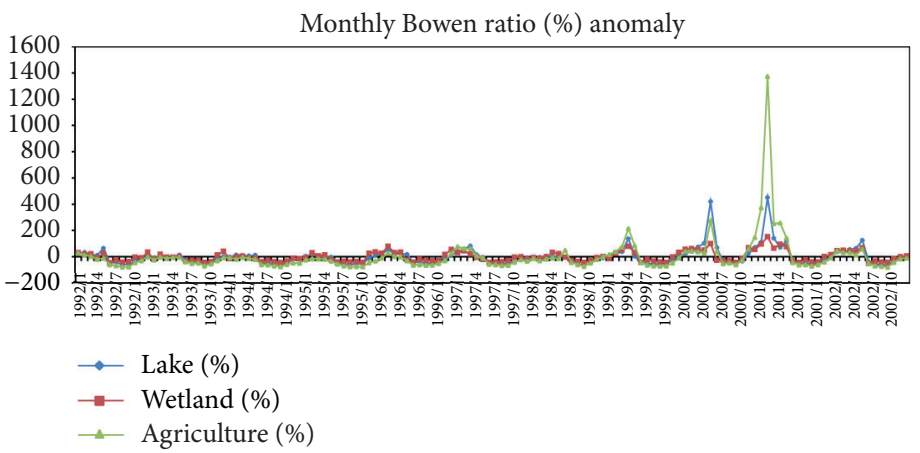

(b)

Figure 16: (a) Time series monthly Bowen ratio anomaly patterns for Northeast Florida. (b) Time series monthly Bowen ratio anomaly patterns for South Florida.

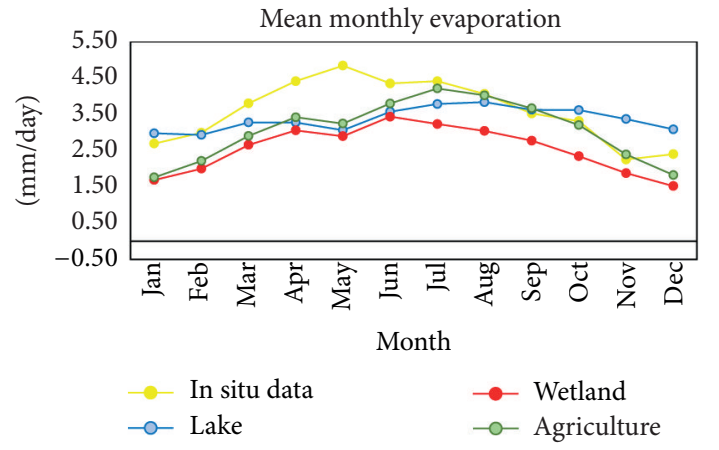

(a)

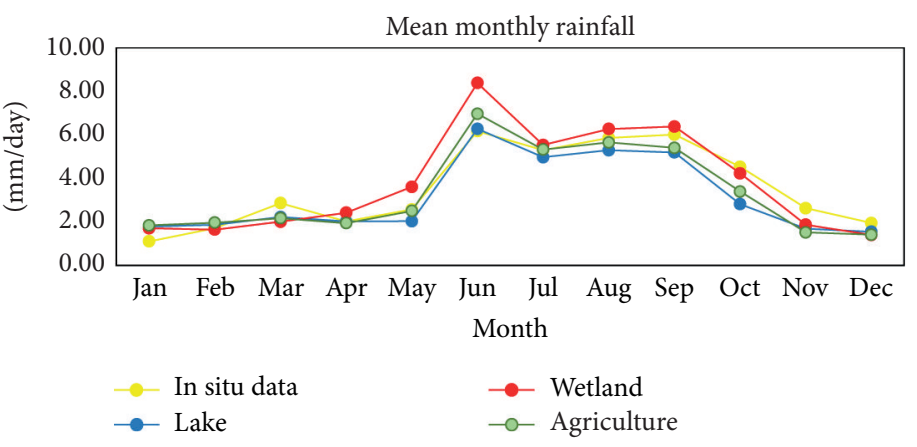

(b)

FIGURE 17: (a) Comparison of average monthly evaporation from the NARR South Florida study areas with the observations at Stormwater Treatment Area 1 West constructed wetland. (b) Comparison of average monthly rainfall from the NARR South Florida study areas with the observations at Stormwater Treatment Area 1 West constructed wetland.

in June 1998, April 2000, and May of 1999 through 2002 for agriculture area, but the forest and urban areas had positive values in these months. In South Florida, the agriculture area had lower evaporation and latent heat within the drought period than the values for the lake and wetland areas. Finally, by comparing them with the observed data, we found out North American regional reanalysis data (NARR) could be used to study the pattern of major hydroclimatic variability (e.g., precipitation recycling) and assess the impacts of land use land cover change impacts.

\section{Conflict of Interests}

The authors declare that there is no conflict of interests regarding the publication of this paper.

\section{Acknowledgment}

This work was supported by the National Science Council (NSC) under the Grants NSC 101-2221-E-008-019 and NSC 101-2111-M-008-018.

\section{References}

[1] Y. Luo, Regional aspects of the North American land surfaceatmosphere interactions and their contributions to the variability and predictability of the regional hydrologic cycle [Ph.D. thesis], 2006.

[2] Y.-A. Liou, "Annual temperature and radiobrightness signatures for bare soils," IEEE Transactions on Geoscience and Remote Sensing, vol. 34, no. 4, pp. 981-990, 1996.

[3] Y.-A. Liou and A. W. England, "A land surface process/radiobrightness model with coupled heat and moisture transport in soil," IEEE Transactions on Geoscience and Remote Sensing, vol. 36, no. 1, pp. 273-286, 1998.

[4] Y.-A. Liou and A. W. England, "Land-surface process/radiobrightness model with coupled heat and moisture transport for freezing soils," IEEE Transactions on Geoscience and Remote Sensing, vol. 36, no. 2, pp. 669-677, 1998.

[5] Y. A. Liou, E. J. Kim, and A. W. England, "Radiobrightness of prairie soil and grassland during dry-down simulations," Radio Science, vol. 33, no. 2, pp. 259-265, 1998.

[6] C. H. Cheng and F. Nnadi, "Water budget on various land use areas using NARR Reanalysis data in Florida," Advances in Meteorology, vol. 2011, Article ID 351350, 13 pages, 2011.

[7] Y.-A. Liou, J. F. Galantowicz, and A. W. England, "A land surface process/radiobrightness model with coupled heat and 
moisture transport for prairie grassland," IEEE Transactions on Geoscience and Remote Sensing, vol. 37, no. 4, pp. 1848-1859, 1999.

[8] G. Hernandez-Ramirez, J. L. Hatfield, J. H. Prueger, and T. J. Sauer, "Energy balance and turbulent flux partitioning in a corn-soybean rotation in the Midwestern US," Theoretical and Applied Climatology, vol. 100, no. 1, pp. 79-92, 2010.

[9] C.-Y. Lin, W.-C. Chen, S. C. Liu, Y. A. Liou, G. R. Liu, and T. H. Lin, "Numerical study of the impact of urbanization on the precipitation over Taiwan," Atmospheric Environment, vol. 42, no. 13, pp. 2934-2947, 2008.

[10] C.-Y. Lin, F. Chen, J. C. Huang et al., "Urban heat island effect and its impact on boundary layer development and land-sea circulation over northern Taiwan," Atmospheric Environment, vol. 42, no. 22, pp. 5635-5649, 2008.

[11] K. Y. Li, M. T. Coe, N. Ramankutty, and R. D. Jong, "Modeling the hydrological impact of land-use change in West Africa," Journal of Hydrology, vol. 337, no. 3-4, pp. 258-268, 2007.

[12] B. F. W. Croke, W. S. Merritt, and A. J. Jakeman, "A dynamic model for predicting hydrologic response to land cover changes in gauged and ungauged catchments," Journal of Hydrology, vol. 291, no. 1-2, pp. 115-131, 2004.

[13] H. C. Pereira, "Keynote paper," in Proceedings of the 10th World Forestry Congress, vol. 3, pp. 139-150, Paris, France, 1992.

[14] L. A. Bruijnzeel, "Hydrology of moist tropical forests and effects of conversion: a state of knowledge review," in UNESCO International Hydrological Program, vol. 224, 1990.

[15] H. H. G. Savenije, "New definitions for moisture recycling and the relationship with land-use changes in the Sahel," Journal of Hydrology, vol. 167, no. 1-4, pp. 57-78, 1995.

[16] Q. Zhang and H. Liu, "Inter-annual variability in the surface energy budget and evaporation over a large southern inland water in the United States," Journal of Geophysical Research: Atmospheres, vol. 118, pp. 4290-4302, 2013.

[17] S. B. Verma, J. K. Joon Kim, and R. J. Clement, "Momentum, water vapor, and carbon dioxide exchange at a centrally located prairie site during FIFE," Journal of Geophysical Research, vol. 97, no. 17, pp. 18629-18639, 1992.

[18] T. E. Twine, W. P. Kustas, J. M. Norman et al., "Correcting eddycovariance flux underestimates over a grassland," Agricultural and Forest Meteorology, vol. 103, no. 3, pp. 279-300, 2000.

[19] L. A. Wever, L. B. Flanagan, and P. J. Carlson, "Seasonal and interannual variation in evapotranspiration, energy balance and surface conductance in a northern temperate grassland," Agricultural and Forest Meteorology, vol. 112, no. 1, pp. 31-49, 2002.

[20] F. Castellví, R. L. Snyder, and D. D. Baldocchi, "Surface energybalance closure over rangeland grass using the eddy covariance method and surface renewal analysis," Agricultural and Forest Meteorology, vol. 148, no. 6-7, pp. 1147-1160, 2008.

[21] T.-Y. Chang, Y.-A. Liou, C.-Y. Lin, S.-C. Liu, and Y.-C. Wang, "Evaluation of surface heat fluxes in Chiayi Plain of Taiwan by remotely sensed data," International Journal of Remote Sensing, vol. 31, no. 14, pp. 3885-3898, 2010.

[22] P. D. Blanken, T. A. Black, H. H. Neumann et al., "Turbulent flux measurements above and below the overstory of a boreal aspen forest," Boundary-Layer Meteorology, vol. 89, no. 1, pp. 109-140, 1998.

[23] M. Aubinet, A. Grelle, A. Ibrom et al., "Estimates of the annual net carbon and water exchange of forests: the EUROFLUX methodology," Advances in Ecological Research, vol. 30, pp. 113$175,1999$.
[24] W. J. Massman and X. Lee, "Eddy covariance flux corrections and uncertainties in long-term studies of carbon and energy exchanges," Agricultural and Forest Meteorology, vol. 113, no. 1-4, pp. 121-144, 2002.

[25] A. G. Barr, K. Morgenstern, T. A. Black, J. H. McCaughey, and Z. Nesic, "Surface energy balance closure by the eddy-covariance method above three boreal forest stands and implications for the measurement of the CO2 flux," Agricultural and Forest Meteorology, vol. 140, no. 1-4, pp. 322-337, 2006.

[26] N. Jarosz, Y. Brunet, E. Lamaud, M. Irvine, J.-M. Bonnefond, and D. Loustau, "Carbon dioxide and energy flux partitioning between the understorey and the overstorey of a maritime pine forest during a year with reduced soil water availability," Agricultural and Forest Meteorology, vol. 148, no. 10, pp. 15081523, 2008.

[27] Y.-C. Wang, T.-Y. Chang, and Y.-A. Liou, “Terrain correction for increasing the evapotranspiration estimation accuracy in a mountainous watershed," IEEE Geoscience and Remote Sensing Letters, vol. 7, no. 2, pp. 352-356, 2010.

[28] P. V. De Azevedo, B. B. Da Silva, and V. P. R. Da Silva, "Water requirements of irrigated mango orchards in northeast Brazil," Agricultural Water Management, vol. 58, no. 3, pp. 241-254, 2003.

[29] F. J. Villalobos, L. Testi, R. Rizzalli, and F. Orgaz, "Evapotranspiration and crop coefficients of irrigated garlic (Allium sativum L.) in a semi-arid climate," Agricultural Water Management, vol. 64, no. 3, pp. 233-249, 2004.

[30] I. A. M. Yunusa, R. R. Walker, and P. Lu, "Evapotranspiration components from energy balance, sapflow and microlysimetry techniques for an irrigated vineyard in inland Australia," Agricultural and Forest Meteorology, vol. 127, no. 1-2, pp. 93-107, 2004.

[31] T. W. Sammis, J. G. Mexal, and D. Miller, "Evapotranspiration of flood-irrigated pecans," Agricultural Water Management, vol. 69, no. 3, pp. 179-190, 2004.

[32] G. Rana, N. Katerji, and F. De Lorenzi, "Measurement and modelling of evapotranspiration of irrigated citrus orchard under Mediterranean conditions," Agricultural and Forest Meteorology, vol. 128, no. 3-4, pp. 199-209, 2005.

[33] T. A. Paço, M. I. Ferreira, and N. Conceição, "Peach orchard evapotranspiration in a sandy soil: comparison between eddy covariance measurements and estimates by the FAO 56 approach," Agricultural Water Management, vol. 85, no. 3, pp. 305-313, 2006.

[34] L. Testi, F. Orgaz, and F. J. Villalobos, "Variations in bulk canopy conductance of an irrigated olive (Olea europaea L.) orchard," Environmental and Experimental Botany, vol. 55, no. 1-2, pp. 1528, 2006.

[35] A. H. D. C. Teixeira, W. G. M. Bastiaanssen, and L. H. Bassoi, "Crop water parameters of irrigated wine and table grapes to support water productivity analysis in the São Francisco river basin, Brazil," Agricultural Water Management, vol. 94, no. 1-3, pp. 31-42, 2007.

[36] F. Mesinger and Coauthors, "North American regional reanalysis," Bulletin of the American Meteorological Society, vol. 87, pp. 343-360, 2005.

[37] Y. Luo, E. H. Berbery, and K. E. Mitchell, "The operational Eta Model precipitation and surface hydrologic cycle of the Columbia and Colorado basins," Journal of Hydrometeorology, vol. 6, no. 4, pp. 341-370, 2005.

[38] R. J. Black, “Florida Climate Data 1," 1993. 
[39] J. Brenner, "Southern Oscillation anomalies and their relation to wildfire activity in Florida," International Journal of Wildland Fire, vol. 1, pp. 73-78, 1991.

[40] J. V. Richard, A. T. Stewart, L. M. Richard, and U. S. Geological Survey, The Drought of 1998-2002: Impacts on Florida's Hydrology and Landscape Circular 1295. System, 2002.

[41] Florida Division of Forestry, "Wildfire statistics for Florida: 1981-present," 2005, http://www.fl-dof.com/wildfire/ stats_fires_since1981.html.

[42] D. R. Carter and E. J. Jokela, Florida's Renewable forest resources, CIR1433, University of Florida, Institute of Food and Agricultural Sciences, Florida Cooperative Extension Service, Gainesville, Fla, USA, 2002.

[43] J. C. Folks, Lake Okeechobee TMDL: Technologies and Research, North Carolina State University, College of Agriculture and Life Sciences, 2005.

[44] G. H. Snyder, Agricultural Flooding of Organic Soils, Bulletin No. 570, Institute of Food and Agricultural Sciences, University of Florida, Gainesville, Fla, USA, 1987.

[45] E. M. Douglas, J. M. Jacobs, D. M. Sumner, and R. L. Ray, "A comparison of models for estimating potential evapotranspiration for Florida land cover types," Journal of Hydrology, vol. 373, no. 3-4, pp. 366-376, 2009.

[46] R. A. Pielke Sr., R. Avissar, M. Raupach, A. J. Dolman, X. Zeng, and A. S. Denning, "Interactions between the atmosphere and terrestrial ecosystems: influence on weather and climate," Global Change Biology, vol. 4, no. 5, pp. 461-475, 1998.

[47] E. A. B. Eltahir, "A soil moisture-rainfall feedback mechanism 1. Theory and observations," Water Resources Research, vol. 34, no. 4, pp. 765-776, 1998.

[48] E. A. Smith, W. L. Crosson, and B. D. Tanner, "Estimation of surface heat and moisture fluxes over a prairie grassland: 1 . In situ energy budget measurements incorporating a cooled mirror dew point hygrometer," Journal of Geophysical Research, vol. 97, no. 17, pp. 18557-18582, 1992.

[49] W. Abtew, "Evapotranspiration in the everglades: comparison of bowen ratio measurements and model estimations," ASAE Paper No. 052188, ASAE, St. Joseph, Mich, USA, 2005.

[50] I. R. Calder, P. T. W. Rosier, K. T. Prasanna, and S. Parameswarappa, "Eucalyptus water use greater than rainfall input-a possible explanation from southern India," Hydrology and Earth System Sciences, vol. 1, no. 2, pp. 249-256, 1997. 

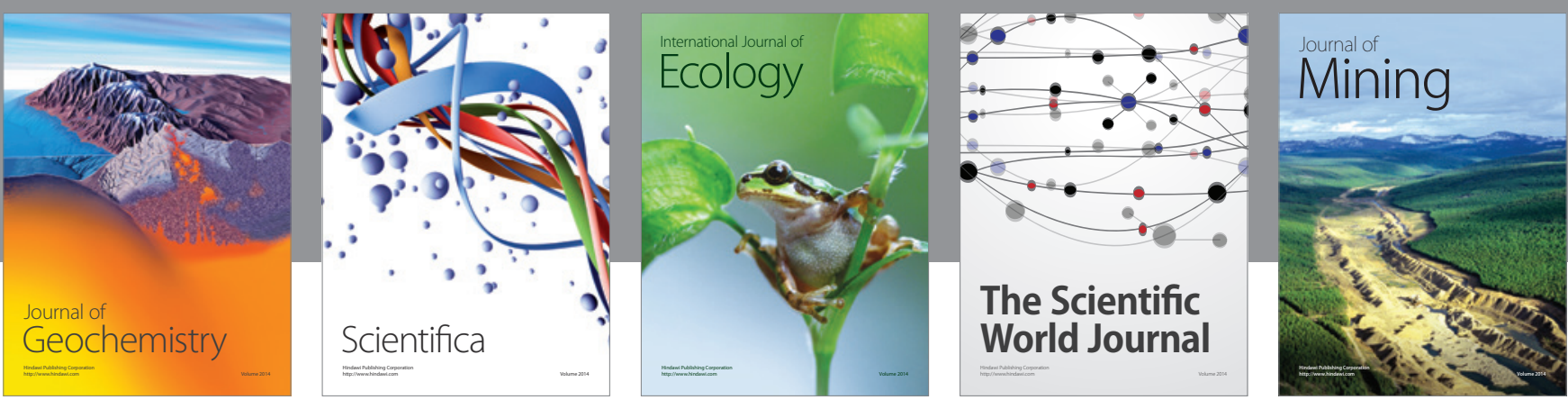

The Scientific World Journal
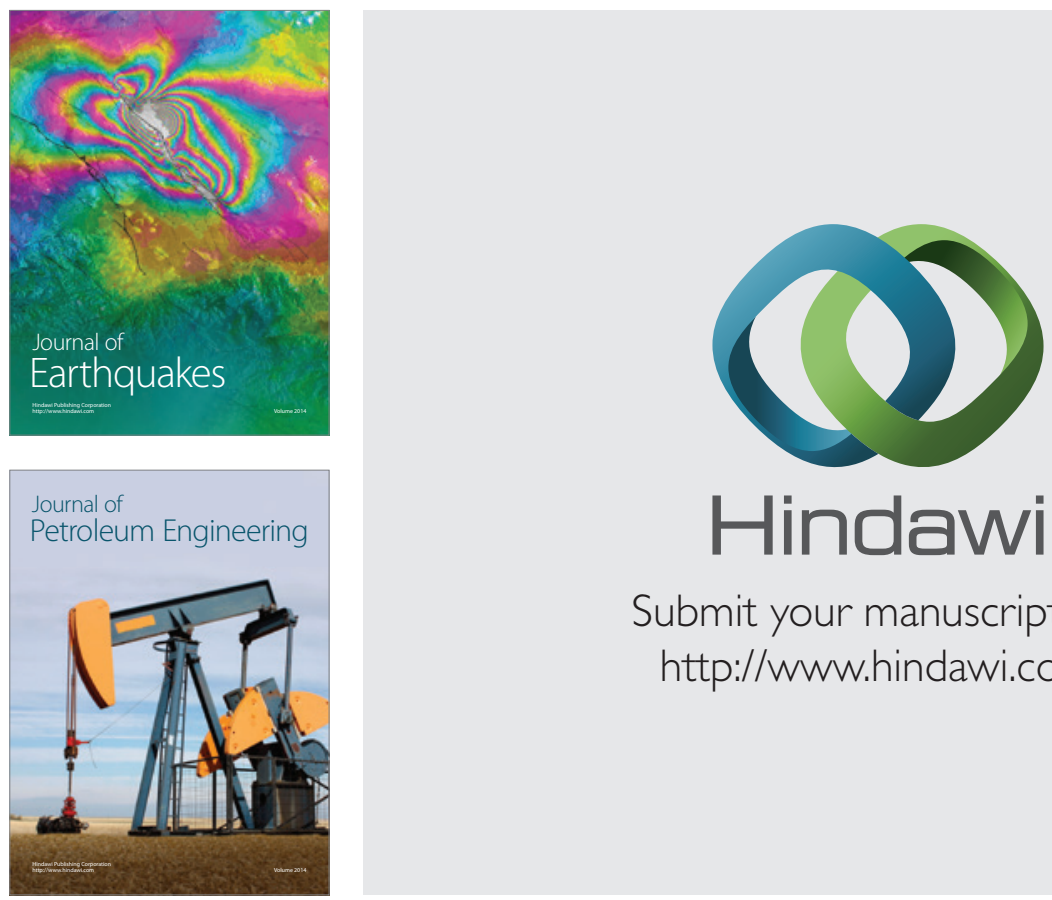

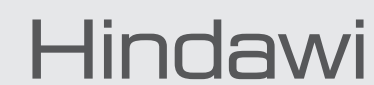

Submit your manuscripts at

http://www.hindawi.com
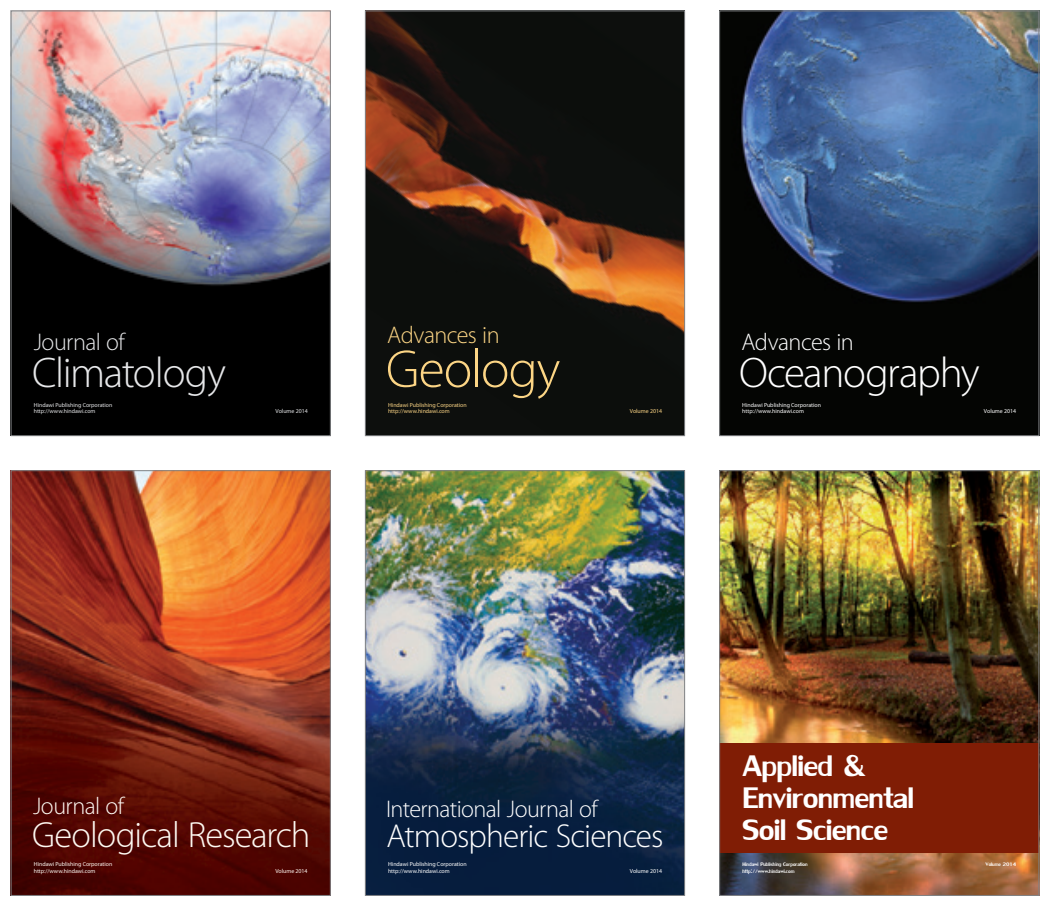
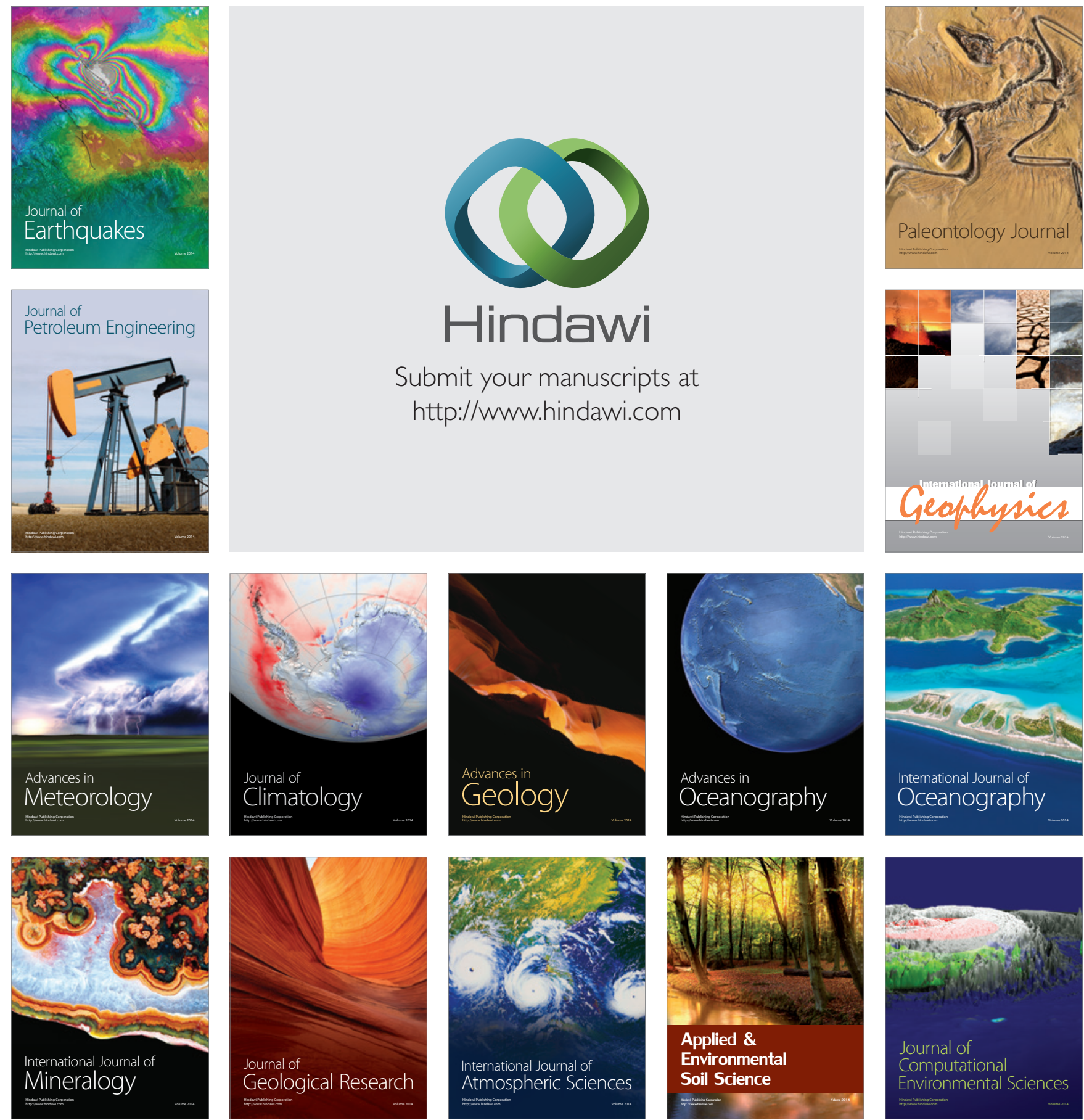